\title{
Quando os laços de amizade e solidariedade são rompidos: questões de disputa e medição de terras e posse de animais
}

\author{
When the bonds of friendship and solidarity are broken: dispute issues and land \\ measurement and possession of animals
}

Cuando amistad y solidaridad se rompen: discute los problemas y la medición de la tierra y la propiedad de los animales

Caroline von Mühlen*

\section{Resumo}

Este artigo analisa alguns confrontos cotidianos e episódios conflituosos ocasionados por questões econômicas envolvendo alemães, seus descendentes e nacionais em São Leopoldo, entre 1846 e 1871. Ao analisar e quantificar os dados de processos criminais, constatou-se que os agentes históricos faziam uso da violência em situações de disputas de terras, problemas decorrentes de medições e invasões de propriedades. Os desentendimentos e os conflitos ocorreram, sobretudo, entre vizinhos, amigos e conhecidos. Assim, as relações sociais, por um lado, podiam ser permeadas por redes de amizade, solidariedade e reciprocidade, mas, por outro, podiam ser rompidas, gerando inimizades, rixas e conflitos. Busca-se, neste texto, atentar para os comportamentos dos indivíduos envolvidos nas querelas, as motivações para as disputas e o contexto histórico dos atores sociais.

Palavras-chave: Cotidiano. Criminalidade. Violência.
Doutora em História pela Pontifícia Universidade Católica do Rio Grande do Sul. Pesquisadora e Vice-Presidente da Associação Nacional de Pesquisadores da História das Comunidades Teuto-Brasileiras. E-mail: carolinevm7@gmail.com

Recebido em 29/03/2017 - Aprovado em 16/05/2017 http://dx.doi.org/10.5335/hdtv.17n.2.7498 


\section{Introducão}

Em 1824, diversos grupos de imigrantes alemães se estabeleceram na recém-fundada Colônia Alemã de São Leopoldo. A chegada de sucessivas levas de imigrantes contribuiu para o surgimento de novas comunidades e exigiu a ocupação de novos territórios, para além da sede/termo de São Leopoldo. Segundo Janaína Amado (2002, p. 79), entre os anos de 1845 e 1857, a população cresceu em torno de 75\%, “[...] espalhando-se pelas dezessete novas picadas abertas na mata" e linhas, como nas picadas "Costa da Serra, Dois Irmãos, Bom Jardim, Picada Café e Linha Hortêncio, isto é, em 712.800 hectares, ou 4,5 vezes mais do que vinte e cinco anos antes" (ROCHE, 1969, p. 269).

O censo de 1846, ano da elevação da Capela Curada à condição de Vila, aponta que São Leopoldo dividia-se em dois termos administrativos e contava com uma população total de 8.476 indivíduos. Alemães, seus descendentes e nacionais contribuíram significativamente para o crescimento e o desenvolvimento econômico. Esse processo

[...] provocou mudanças radicais na estrutura interna da colônia. Houve alterações sensíveis e rápidas no processo produtivo, na rede fundiária, nas relações sociais, na política e na religião (AMADO, 2002, p. 79).

Em 1858, ao visitar a Vila, o alemão Avé-Lallemant observou que os moradores da Feitoria Velha "travaram lutas sangrentas e contendas com vizinhos que se apropriaram, na medição, de mais terras do que lhe competia" (1980, p. 141). Dos 18.690 indivíduos contabilizados em 1858, mais de 77\% viviam no entorno do Termo da Vila, isto é, nos distritos que eram as áreas mais rurais.

No presente artigo, busca-se atentar para os comportamentos e as atitudes de indivíduos do mundo rural de São Leopoldo, diante do surgimento de situações que envolviam a posse de terra e de animais. ${ }^{1}$ Numa observação mais atenta aos processos criminais, é possível perceber que os motivos elencados pelos envolvidos para cometer um ato de violência foram insultos, rixas e divergências antigas, problemas com abertura e fechamento de caminho, dívidas e negócios mal resolvidos, medição e demarcação das divisas, invasão e destruição da lavoura por algum animal do vizinho. Esses motivos dão um indicativo da existência de problemas de convívio e de relacionamento entre os vizinhos nos distritos, tendo origem em questões de terra, propriedade e posse, sendo, porém, um reflexo das condições sociais, econômicas e políticas vivenciadas pelos habitantes de São Leopoldo.

Dessa forma, objetiva-se questionar a ideia consolidada pela historiografia de que as relações sociais nas comunidades rurais estavam pautadas unicamente pela lógica dos laços comunitários. Não se quer, de modo algum, dizer que os indivíduos não estabeleciam laços de solidariedade, amizade e reciprocidade com os vizinhos, pelo contrário, reforça-se a necessidade desses laços para garantir sua sobrevivência, por meio de interação e cumplicidade entre os indivíduos que viviam nas casas próximas. Se, por um lado, esses laços garantiriam auxílio, ordem e harmonia local, por outro, era nesse ambiente e entre os vizinhos que 
surgiam conflitos, desentendimentos e julgamentos mais graves.

Diferentes eram os motivos que podiam desestabilizar as relações entre as famílias nas comunidades coloniais [...] o contato cotidiano e a proximidade das casas favoreciam os surgimentos de atritos (VENDRAME, 2013, p. 387).

\section{Crimes na vizinhança}

No dia 4 de setembro de 1866, por volta das 2 ou 3 horas da tarde, no local denominado Bom Jardim ( $4^{\circ}$ distrito), Nicolau Schuck e a sua família entraram em conflito com a Comissão encarregada pelo governo para a medição das colônias do Município de São Leopoldo. Os engenheiros Martinho Domingos Pinto Braga e Leon von Langendonck, as testemunhas Francisco Fagundes de Nascimentos, Antônio Cardoso e Antônio Nunes de Oliveira, além dos praças da polícia municipal, foram enviados a São Leopoldo pelo Comissário Especial do Governo, Dr. Francisco Carlos L. Cunha, para averiguação e medição da divisa das colônias dos alemães e vizinhos Felipe Diefenthäler e Nicolau Schuck, com o intuito de fixar os marcos divisórios.

Na primeira audiência, os réus foram ouvidos e apresentaram suas versões sobre os fatos. Nicolau Schuck alegou que ele e sua família não agiram com violência contra a comissão responsável pela medição, nem sequer dispararam tiros contra seus membros. Afirmou, apenas, que se dirigiu ao local da medição para informar à comissão "que ali não era o lugar aonde se devia fincar os mar$\cos ^{\prime \prime}$ e que, se tal medição fosse efetivada, "muito o prejudicaria em suas terras, por se apartar das divisas antigas", ${ }^{2}$ que, segundo o réu, existiam há mais de vinte anos e regulavam os limites de sua propriedade. Não sendo atendido o seu pedido, retornou para casa com o filho Cristóvão, quando foi avisado pela esposa, Ana Margarida Schuck, de que alguns terneiros haviam destruído a cerca e fugido. Naquele instante, solicitou aos filhos Cristóvão, Adão, Pedro e Catarina, acompanhados por Ana Margarida, que fossem até o local, fechassem os buracos por onde os animais haviam fugido e capturassem os terneiros. Saindo a cavalo para verificar o fato, deparou-se novamente com a comissão. Julgando a medição incorreta, solicitou ao empregado João Luiz Weber que não fixasse os marcos divisórios naquele local. O réu afirmou que os engenheiros responsáveis interromperam a medição e se retiraram do local, sem dar maiores explicações.

As oito testemunhas inquiridas para depor sobre o caso integravam a comissão de medição e trabalhavam no momento do conflito. A primeira testemunha, Nicolau Closs, disse que, chegando ao local, a comissão logo iniciou a averiguação e a medição na propriedade, bem como realizou a colocação dos marcos na divisa. No entanto, poucos minutos depois, apareceram no local, primeiramente, Nicolau e Pedro Schuck para verificar o que estava ocorrendo. Em seguida, retiraram-se ambos para casa, que ficava perto do lugar do conflito, e retornaram ao local acompanhados pelos demais integrantes da família. Todos estavam armados: Ana Margarida e Catharina portavam cacetes, Nicolau, a cavalo, segurava um relho, Cristóvão levava uma foice, Adão estava 
armado com um machado e Pedro portava uma arma de dois canos, com a qual disparou dois tiros contra o engenheiro Martinho Domingos Pinto Braga e o auxiliar João Luís Weber, para impedir que continuassem a medição e a colocação dos marcos. Diante dessa situação, a comissão lavrou um documento sobre o ocorrido e retirou-se da propriedade da família Schuck.

As demais testemunhas confirmaram a versão apresentada por Nicolau Closs, de que os réus não concordavam com a medição e, por isso, uniram-se para não permitir a colocação dos marcos. Carlos Habigzang complementa dizendo que o réu Nicolau não "consentia que se lhes furtassem as suas terras", por isso teria agido com violência. Dada a palavra aos réus e ao curador "do menor e idiota" 3 Pedro Schuck, eles contestaram os depoimentos, alegando que o depoimento das últimas cinco testemunhas era suspeito, pois se tratavam de empregados da comissão, e questionaram o depoimento das três primeiras testemunhas, alegando que eram inimigos da família. Com a primeira testemunha, a inimizade era pelo fato de ela, "há 14 dias mais ou menos, ter invadido as terras de sua colônia e arrancado as plantações de uma de suas roças"; com a segunda testemunha, teve uma divergência "há dois meses por causa dos limites", ${ }^{4}$ e com a terceira, que também era um de seus vizinhos, Diefenthäler, não mantinha relações amistosas pelo mesmo motivo da anterior.

Indiciados pelos crimes de resistência à ordem legal e pela tentativa de homicídio, os réus foram condenados às penas respectivas do Código Criminal de 1830. Assim, em 31 de janeiro de 1867, o Juiz de Direito proferiu a sentença, condenando Nicolau e Cristóvão a dois anos e onze meses de prisão simples, Ana Margarina, Adão e Catharina a um ano e dois meses de prisão simples, mais as custas processuais, e, de acordo com o que se provou nos autos criminais, "que o réu Pedro Schuck é idiota", foi absolvido da acusação que lhe foi intentada. Apesar da decisão imposta pelo Juiz de Direito, os réus que se uniram para impedir a medição de sua propriedade não permaneceram presos, pois, por meio do "decreto de 10 de abril último pelo qual S. M., o Imperador, houve por bem perdoar" aos réus Nicolau, Cristóvão, Adão, Ana Margarida e Catharina Schuck "o tempo que lhes falta por este juízo" ${ }^{5}$

$\mathrm{O}$ caso relatado apresenta alguns aspectos peculiares do cotidiano de uma sociedade rural e reforça uma problemática muito comum em São Leopoldo, no Rio Grande do Sul e no Brasil do século XIX e XX, envolvendo pequenos proprietários/colonos e as questões de falta de marcações ou de limites indecisos das fronteiras das propriedades. Constatamos que nem sempre o motivo de rixas, divergências e insultos entre os envolvidos ficaram evidentes nos processos criminais, no entanto, partimos do pressuposto de que os casos como o da família Schuck foram mais frequentes do que indicam os dados compilados dos autos criminais. É necessário notar que, ao invés de acionar a esfera judicial para solucionar a questão, os habitantes optavam pela resolução do conflito por meio do uso da violência física. Assim, os conflitos eram denunciados como crime contra a pessoa, e não como crime contra a propriedade; outros, todavia, sequer foram denunciados, como os dois 
casos citados pelo réu Nicolau, ao longo do processo, contra o sapateiro Nicolau Closs e o negociante Jacob Knierim, além do caso em questão, em que o lavrador Felipe Diefenthäler solicitou a medição e a demarcação da colônia.

Dos 97 processos criminais compilados, identificamos que 49 ocorreram no âmbito privado do cotidiano dos indivíduos, ou seja, em espaços correspondentes à propriedade e/ou à residência dos réus e das vítimas. Dessa amostragem, somente oito processos $(8,2 \%)$ foram julgados como crimes contra a propriedade, mesmo sendo esse o motivo do conflito entre as partes em outros processos. Por isso, iremos analisar aqueles casos cujas práticas de violência estavam relacionadas, especialmente, a aspectos socioeconômicos. Para que possamos entender o caso envolvendo a família Schuck e também outros, é necessário fazer algumas ressalvas acerca da questão fundiária da região, sobretudo sobre os problemas vislumbrados por Tramontini antes da aprovação e decorrentes da Lei de Terras de 1850.

Em 18 de setembro de 1850, sob a Lei $\mathrm{n}^{\circ} 601$ (BRASIL, 1850), foi promulgada a primeira legislação agrária no Brasil, com o objetivo de resolver questões e situações acerca da ocupação da terra no seu território, ou seja, "transformar as terras, até então declaradas como posses e concessões, em propriedade" (OLIVEIRA; TRAMONTINI, 2004, p. 362). Com esse intuito, criou-se uma Repartição Geral de Terras Públicas, para dirigir a medição, a divisão, a descrição e a conservação das terras devolutas, fiscalizar a venda e a distribuição delas, promover a colonização nacional e estrangeira, além de revalidar títulos e legitimar a posse de terras anteriormente adquiridas (art. 21). A Repartição Geral, segundo Márcia Motta,

[...] teria, em suma, não somente a responsabilidade de discriminar as terras públicas das privadas, mas de definir fronteiras entre elas, reconhecer ou não as fronteiras entre fazendas e entre fazendas e sítios (2008, p. 61).

É importante lembrar que, antes desse período (1822-1850), não houve nenhuma lei que normatizasse e regulamentasse o uso e a exploração das terras em território brasileiro. Mesmo sem a posse legal da terra, ela era avaliada, comprada, vendida e revendida pelos ditos proprietários (FREITAS, 2014, p. 103). Dessa forma, os latifundiários foram ampliando as suas extensões territoriais, enquanto pequenos e médios proprietários, em decorrência da falta de limites definidos, eram expropriados de suas terras. “Era preciso ser influente na administração para tornar-se proprietário ou garantir a propriedade" (TRAMONTINI, 2003, p. 35). Essa situação caótica em relação ao acesso e à preservação dos lotes coloniais ocasionou tensões, conflitos e divergências entre pequenos, médios e grandes proprietários antes da aplicação da Lei de Terras.

A nova lei deveria fornecer condições para minimizar a problemática envolvendo o acesso à terra e legitimar as posses. No entanto, ela expressou, principalmente, os interesses dos grandes proprietários e latifundiários, dificultando o acesso à posse da terra para muitas pessoas das camadas mais pobres e médias da população. A partir dessa lei, a propriedade só poderia ser adquirida por compra e mediante um comprovante 
(autos de medição e legitimação de posses e títulos de propriedade), documento que os colonos alemães não haviam recebido quando chegaram em 1824, uma vez que a propriedade que possuíam foi doada pelo governo imperial.

Dessa forma, a partir de 1850, o governo imperial deveria realizar medição nos lotes coloniais, a fim de instituir um cadastro de terras e regularizar a posse e a ocupação não só em São Leopoldo, mas, sobretudo, em todo o Rio Grande do Sul e no Brasil. Todavia, como bem demonstrou o caso que introduziu esse artigo, nem sempre os colonos e proprietários dos lotes coloniais operavam e cooperavam com os dispositivos da lei, pois, a partir de seus próprios interesses, muitos se recusavam a permitir que o Estado regularizasse a ocupação territorial com medição e demarcação das colônias dos municípios. Márcia Motta lembra que "alguns poderiam vislumbrar os benefícios da lei para a consagração de seus limites territoriais, outros poderiam sentir-se ameaçados ao identificar no registro um limite ao seu poder, que poderia consubstanciar-se na delimitação física e precisa de sua terra" (2008, p. 60). A família Schuck, por exemplo, ao unir-se para impedir a medição e a demarcação das divisas, estava tentando proteger o seu patrimônio, pois perder uma parcela de terra para o vizinho Diefenthäler poderia resultar em prejuízos para a família e aumentar as dificuldades cotidianas.

A origem dos conflitos que ocorreram na Colônia Alemã de São Leopoldo, segundo Tramontini (2003, p. 37), é relativa às disputas por terras e à tentativa de enquadramento dos colonos à estrutura fundiária brasileira. A partir da segunda metade dos anos 20 do século XIX, quando foram estabelecidas as primeiras famílias, os contratos de imigração não foram cumpridos de forma regular pelo governo brasileiro, principalmente, em relação à demora e à falta de medição e demarcação judicial dos lotes. O resultado dessa situação de negligência deixou São Leopoldo:

[...] num estado de confusão irremediável, como foco de pleitos judiciais que envolviam os colonos, 'sem culpa alguma dessas irregularidades', em questões de reivindicação de terras, e que os expunha à 'odiosidade de muitos nacionais que nunca puderam ver esses colonos possuidores de terras que lhes pertenciam, sem que neles não se despertasse o ódio' (TRAMONTINI, 2003, p. 60).

Esse processo confuso e conflituoso não "se estenderia até aqueles dias do final da década de 50", como afirma Tramontini (2003, p. 61), mas continuaria em pauta, revelando-se um desdobramento dos primeiros cinquenta anos do século XIX, acrescido de novas problemáticas impostas pela Lei de Terras, como derrubada de marcos divisórios, medidas e ações judiciais, agressões e assassinatos para garantir o domínio territorial. Corroborando essa afirmação, Dóris Rejane Fernandes Magalhães, com base no ensaio de James Holston, "Legalizando o ilegal: propriedade e usurpação no Brasil", afirma que a intenção do sistema jurídico brasileiro não era resolver os conflitos e desentendimentos oriundos da questão de terras, uma vez que a própria Lei de Terras não promovia soluções, mas, sim, conflitos, tornando-a "um instrumento de manipulação, complicação, estratagemas e violência" 
(2007, p. 482). Segundo Magalhães (2007, p. 484), os habitantes de São Leopoldo e possuidores de terras optaram por registrar suas propriedades no Vigário, ao invés de dar continuidade ao processo de medição e demarcação das terras, conforme previa a Lei de Terras e o Regulamento de 1854, revelando, por um lado, que esse registro era considerado pelos possuidores como suficiente para garantir a posse da terra e, por outro, que esses indivíduos estavam medindo forças por opção contra as autoridades, ao descumprir a lei que exigia a medição e a demarcação da terra para receber o título de posse e manter o seu domínio ou por desconhecimento das leis. Dessa forma, a Lei de Terras e o Regulamento de 1854 somente foram cumpridos 25 anos após a sua criação. De acordo com Magalhães:

[...] esse processo não foi pacífico porque houve manipulação, complicações e estratagemas para garantir a posse. Nesse momento emerge o problema da falta de clareza, da indefinição das divisas, de agregados que se tornam empregados, terras colocadas em nome de terceiros, de permitir a presença de 'compadres' nas divisas para comprovar a posse e a ocupação com aproveitamento, de interpretação das informações passadas pelos medidores de terra, das decisões judiciais (2007, p. 485).

Com a chegada de novas levas de imigrantes, ao longo do século XIX, o aumento populacional, a expansão da colônia, o desenvolvimento econômico e um lento processo de urbanização favoreceram a expansão de São Leopoldo e, também, a crescente valorização da terra. A alta dos preços da braça quadrada da terra, a especulação e a concentração da propriedade da terra nas mãos de poucos, a falta de regulamentação de propriedade e a proibição da doação de terras provocaram choques de interesses e conflitos, disputas, contratempos e reclamatórias, principalmente na área rural de São Leopoldo, correspondendo a $68 \%$ dos casos, ao longo da segunda metade do século XIX.

Em Soledade, a historiadora Hellen Ortiz constatou que:

[...] enquanto corriam as décadas e os trâmites burocráticos, as terras de que tratavam os autos eram exploradas, compradas, vendidas, herdadas, usurpadas e/ ou colonizadas por particulares e também pelo próprio poder público (2014, p. 129).

Ela observou, ainda, que a aplicação da Lei de Terras de 1850 foi um processo longo, complexo e que deu origem a conflitos motivados pela

[...] falta (ou demora) de legalização e também quando da oficialização das medições e regularizações. [...] pela permanência da prática de compra e venda de terrenos indivisos ou sem extensão precisa (2014, p. 129).

Um caso semelhante ao da família Schuck ocorreu em 1849, quando a viúva Maria Joaquina da Conceição, dizendo-se "senhora e possuidora de mais de quinze anos de terras, matos e capoeiras", situadas no local denominado Boa Vista ( $2^{\circ}$ distrito), "entre a estrada velha que vai de Santa Cruz até o arroio do mesmo nome", moveu uma ação de expulsão dos intrusos, restituição de posse das ditas terras e reparação dos danos causados contra os réus João Feliciano Jaques, José Henrique Correa e Joaquim José de Souza. Acontece que, após o falecimento do marido, "retirando-se a suplicante e a sua família por algum tempo da própria casa", 
a propriedade foi invadida e ocupada pelos réus, que realizaram várias plantações, roçaram os matos, extraíram as madeiras, queimaram uma grande porção de capoeiras, além de construir um casebre de palha "para apropriar-se do dito terreno da suplicante, esbulhando-a desse direito e propriedade". Assim, os três réus eram acusados de estar ocupando arbitrariamente as terras de Maria Joaquina da Conceição, viúva de Francisco de Paula Figueiredo, além de se apossar e plantar na área citada, sem aprovação e concessão da proprietária, causando-lhe diversos danos. ${ }^{6}$

Após aceitar a queixa, o subdelegado de Polícia autorizou a autuação de um auto de exame e corpo de delito na propriedade da autora. Os peritos nomeados, juntamente com as demais autoridades, dirigiram-se ao lugar da residência do finado Francisco de Paula Figueiredo para verificar se na propriedade havia a presença de intrusos e quais eram os danos provocados. $\mathrm{Na}$ ocasião da perícia, encontraram a edificação de cercas, o plantio de algumas roças de milho, derrubada de roças, matos e capoeiras, corte e extração de madeiras e a edificação de um casebre de palha, construído recentemente, avaliando o dano em duzentos mil réis.

Segundo as cinco testemunhas inquiridas, as divergências entre os vizinhos por demarcação dos limites e invasão de propriedade não eram recentes. Sapriano José de Vargas afirma que o réu José Henrique Correa tentou apropriar-se de uma parte do sítio de Francisco de Paula Figueiredo (antes de ele ser assassinado), realizando uma plantação nos fundos da dita propriedade. O finado Figueiredo, por sua vez, também estabeleceu uma roça nas suas divisas para impedir que o vizinho invadisse e se apropriasse de parte de suas terras e ainda extraísse e comercializasse o mato de sua propriedade. Sobre essa questão, outra testemunha elucida melhor o caso, informando que João Feliciano Jaques e Joaquim José de Souza, algumas vezes, invadiram a propriedade do finado, à noite, para derrubar árvores e comercializar a madeira. Denunciados, foram embargados judicialmente e obrigados a pagar o valor correspondente aos danos causados na propriedade.

Conforme consta nos autos criminais, Maria Joaquina da Conceição e Francisco de Paula Figueiredo haviam adquirido a propriedade há alguns anos, "onde se estabeleceram com uma casa, um engenho de moer cana, arvoredo de espinhos e outras árvores de frutas". ${ }^{7}$ Pelos depoimentos, é possível supor que a família, provavelmente, não possuía um documento ou título de propriedade, nem sequer havia solicitado a medição e demarcação precisa das divisas, pois todas as testemunhas informaram que não houve a imposição de nenhuma pessoa quando a família se apossou da dita propriedade. Em 1849, ano do processo, ainda não existia uma lei que regulamentasse a posse da terra, logo, acreditamos que Figueiredo, ou algum antepassado seu, tenha se apropriado dessa área devoluta, e lá estabelecido seu meio de sobrevivência.

Os réus alegaram que não cometeram crimes de dano, pois somente se estabeleceram nas roças que não eram de propriedade do finado Figueiredo. Em contralibelo, temos a informação de que os intrusos João Feliciano e José Henrique Correa realizaram 
plantações nas terras pertencentes a Manoel Fialho Vargas e o réu Joaquim José de Souza, nas terras de José Antônio Fernandes. Já no interrogatório, o réu João Feliciano Jaques afirmou ter comprado as ditas terras, considerando, pois, legítima a ocupação da área. As informações confusas, os embates para justificar quem era de fato o dono da propriedade e a falta de um documento de posse contribuíram para que os jurados decidissem, em sessão de 26 de janeiro de 1850 , que os réus não cometeram o crime de dano e nem sequer destruíram e danificaram os terrenos e matos do sítio da autora, conforme alegou na queixa. ${ }^{8}$

Inúmeros foram os desentendimentos e conflitos ocorridos no mundo rural imperial. Tratam-se, sobretudo, de disputas por lotes coloniais, ausência de medição e demarcação precisa das divisas, invasão e destruição de propriedade, situações que provocaram as mais distintas reações nos indivíduos. Observamos que a agressão física e/ ou verbal era a prática mais comum, pois, na maioria das vezes, a violência foi utilizada pelos envolvidos como o meio mais rápido e viável para resolver a questão. Poucos foram, contudo, os crimes contra a propriedade, em que os envolvidos provocaram algum tipo de dano no espaço em questão.

Além do caso narrado anteriormente, envolvendo Maria Joaquina da Conceição, vejamos mais detalhadamente a queixa de crime de dano apresentada por Mathias Utz, no ano de 1868, contra cinco lavradores e moradores no mesmo distrito do litígio.

$\mathrm{O}$ crime de dano ocorreu no dia $1^{\circ}$ de maio de 1868, às 10 horas da manhã, no local denominado Picada dos Dois Irmãos $\left(4^{\circ}\right.$ distrito). A vítima Mathias Utz alegou na denúncia ter justos motivos para queixar-se dos lavradores alemães e teuto-brasileiros Mathias Elwanger, João Schneider, Gabriel Korndörfer, Jacob Berlitz e Felipe Hess, que "de livre arbítrio e sem o consentimento do suplicante [os réus] passaram a derrubar as cercas de espinho de maricá que fechava a frente de sua colônia e o potreiro que cercava os seus animais, prejudicando, assim, gravemente ao suplicante em sua legítima propriedade". ${ }^{9}$ Disse, ainda, ser "senhor e possuidor" de meia colônia de terras de matos, sob o número 7, localizada à direita da Picada dos Dois Irmãos, adquirida no ano de 1867, por um conto e quinhentos mil réis, do casal Jacob Blauth e sua esposa Luiza Konrardt. "Livre de hipoteca", ${ }^{10}$ existia nessa meia colônia uma casa de moradia e outras benfeitorias, além de um espaço para plantação e criação de animais. Fazia divisa, pelo norte, com a colônia de Martin Elwanger (provavelmente parente do inspetor) e, pelo sul, com as terras do casal Jacob Blauth e Luiza Konrardt.

Assim, no mesmo ano de 1868, Mathias Utz requereu ao subdelegado de polícia do distrito que efetuasse um auto de exame de corpo de delito nas suas terras e cercas, com o objetivo de comprovar o sério transtorno e dano (calculado no valor de um conto e seiscentos mil réis) causado nas referidas cercas derrubadas pelos réus, sob a ordem do inspetor de quarteirão Mathias Elwanger. Para efetuar a diligência, o subdelegado de polícia convidou moradores da comunidade local, nomeando como peritos os colonos Jacob Dienstmann e João Korndörfer, que, ao examinar as cercas, encontraram partes da frente e do potreiro completamente der- 
rubadas, em torno de vinte e sete braças de cumprimento, estimando um prejuízo de vinte e sete mil réis.

As cinco testemunhas confirmaram ser Mathias Utz possuidor das terras alegadas e que os réus foram os responsáveis pela destruição da cerca que protegia a frente e o potreiro da propriedade, porém, não souberam dizer ao certo qual o motivo que levou os réus a praticar aquele ato. A primeira testemunha, Jacob Blauth, todavia, encontrava-se no local na ocasião do crime, visto que também trabalhava na compostura da estrada, e elucidou melhor a questão. Em conformidade com as suas declarações, no dia $1^{\circ}$ de maio, viu o inspetor de quarteirão chegar ao local e declarar que:

[...] ia avisar o queixoso para compor a estrada em frente as suas terras, aparecendo logo depois os réus presentes, que ele testemunha supôs que o viessem ajudar na compostura da estrada e fazendo-lhes perguntas neste sentido foi-lhe respondido pelo réu Felipe Hess que eles não iam ajudar, mas vinham para derrubar a cerca. ${ }^{11}$

Dessa forma, foram pronunciados como réus, pelo Juiz Municipal, João Schneider, Gabriel Korndörfer, Jacob Berlitz e Felipe Hess, e o inspetor de quarteirão Mathias Elwanger foi despronunciado.

Uma observação mais atenta às entrelinhas dos depoimentos das vítimas e dos réus envolvidos no processo e à contestação escrita apresentada pela defesa permite supor que o motivo do conflito entre as partes envolvidas não era somente a destruição da cerca de maricá e os prejuízos causados pelo ato, conforme alegou o autor, mas, sim, antigas inimizades entre Mathias Utz e a família Elwanger.
Tanto o defensor dos réus quanto o próprio inspetor de quarteirão afirmam que o autor e as suas testemunhas "são inimigas declaradas" de Mathias Elwanger e sua família, "e só a fim de prejudicá-lo podia fazer com que ele viesse a juízo". ${ }^{12}$ Outro fato que corrobora o nosso argumento é a informação de que a propriedade do autor fazia divisa, ao norte, com a colônia de Martin Elwanger, provavelmente algum parente do inspetor e com o qual deve ter travado conflitos anteriores por questões de medição e demarcação de divisas. Por fim, o procurador do autor, Epifânio Fogaça, não concordando com a sentença dos jurados, apelou para o Tribunal da Relação do distrito, solicitando novo julgamento.

Outra situação cotidiana bem frequente em São Leopoldo, principalmente na área mais rural, envolvendo colonos e pequenos lavradores foram as acusações de invasão e destruição de lavouras por animais, além de alguns casos de sumiço ou furto de animais, que desapareciam das propriedades e, muitas vezes, eram incorporados ao rebanho daqueles que tinham suas lavouras destruídas pelos animais dos vizinhos. Constatamos que a abertura do processo criminal foi motivada pela destruição de uma cerca de maricá utilizada para marcar a divisa da propriedade e cercar o potreiro de Mathias Utz. É importante lembrar que as autoridades locais debatiam constantemente a questão e exigiam que os colonos fizessem cercas, para impedir que os animais destruíssem as lavouras dos vizinhos. Concordamos com Deivy Carneiro, quando afirma que "geralmente o acusado pelo roubo era um vizinho ou parente; aquele que possuía terras e animais fronteiriços à propriedade da vítima ou aqueles vizinhos 
que eram negociantes de animais e que assim teriam motivo para roubar o animal e se desfazer dele rapidamente" (2008, p. 329). A reação ou estratégia do indivíduo que tinha algum animal roubado ou lavoura destruída podia ser variada. A parte prejudicada podia somente difamar publicamente o autor do ato (crime de ofensa verbal e injúria), em outros momentos, chamar em público e ameaçá-lo a devolver o animal roubado (crime de homicídio, tentativa de homicídio, ofensas físicas e ferimentos), mas também podia acionar a polícia, para tentar reaver seu bem ou obter a justiça para restituir o prejuízo.

$\mathrm{O}$ caso envolvendo os vizinhos João Sparrenberger, Jorge S., Carlos S., Maria Ana, viúva de Carlos Sparrenberger, e João Felipe Dieter deu origem a três processos criminais de ofensas físicas e ferimentos. Em 1865, os indivíduos citados se encontravam na casa de negócios de Martin Stumpf, localizada no Mundo Novo ( $6^{\circ}$ distrito), por ocasião de um baile público, quando, por volta das 21 horas, iniciou um "barulho", que resultou em inúmeros ferimentos e na morte de Carlos Sparrenberger, alguns dias depois do ocorrido. No primeiro auto criminal, a queixa foi apresentada pelo lavrador e curtidor João Felipe Dieter, contra a família Sparrenberger, porém, ao longo do processo, não fica claro o motivo do conflito. Sabemos, porém, que as duas famílias eram inimigas, e o autor "não fala a mais de 3 anos" com a outra parte. ${ }^{13}$

Os depoimentos das sete testemunhas que se encontravam na casa de negócio na ocasião do conflito também não esclareceram o motivo das ofensas físicas e dos ferimentos, mas alegaram que o autor era inocente. O marceneiro João Fisch disse que viu e ou- viu quando João Felipe Dieter foi insultado e injuriado por Carlos Sparrenberger com o termo "João-cachorro", ${ }^{14}$ e essa ofensa teria ocasionado o conflito, quando Dieter tentou defender-se com o cabo de um relho. Já a testemunha, Frederico Sander, viu João Felipe Dieter ser empurrado por Carlos Sparrenberger. Nessa ocasião, apareceu João, irmão de Carlos, e agarrou a vítima, dando origem às agressões. A defesa dos réus, bem como as testemunhas de defesa, por sua vez, apresentou outra versão dos fatos:

João Felipe Dieter, tendo há tempos ameaçado aos acusados de lhes tirar as tripas com uma faca, julgou consumar o seu danado intento no dia 5 do mês de fevereiro do corrente ano, aproveitando a oportunidade de um baile público. Então, premunido de uma grande faca de ponta, foi ao baile e logo que avistou Carlos Sparrenberger, que se achava dentro do balcão, atirou-lhe uma facada em direção ao peito esquerdo, que desviando-se do golpe, contudo, o foi ferir no braço do mesmo lado, e tão gravemente, que faleceu dez dias depois! E logo [...] chegando João Sparrenberger, vendo seu irmão ferido, que desarmado, lançando mão da folha de faca, que sendo puxada por Dieter, o feriu na mão e o autor dela, atirou-lhe um golpe na orelha esquerda! Em seguida, chegando a porta do quarto onde estava tomando café Jorge Sparrenberger, Dieter, [...] continuou, dirigindo-se a Jorge, que o agarrando, foram lutando até dentro do quarto, onde conseguindo derrubá-lo no chão para desarmá-lo, segurou o ferro homicida, [...] chegando por trás um companheiro de Dieter, o tirou de cima deste dando lugar a que Dieter, autor da faca, o ferisse sobre o lado esquerdo, gravemente. Então, [...] procurou fugir, sendo perseguido por quase todos os indivíduos que haviam presenciado [...] a fim de desarmá-lo, o que só conseguiram à força, ficando ferido na cabeça e no braço. ${ }^{15}$ 
Diante das versões contrárias, em que tanto a vítima quanto os réus julgaram-se inocentes, o Juiz de Direito José Alves de Azevedo Magalhães proferiu, em 25 de maio de 1865, a sentença que absolveu os réus da acusação. Os réus, no entanto, também moveram uma ação contra João Felipe Dieter, três dias após a primeira, dando origem a dois processos criminais. Neste processo, foram apresentadas informações mais esclarecedoras acerca do motivo do conflito ocorrido no dia 5 de fevereiro. Assim, a família Sparrenberger, por meio do seu procurador, Francisco Ferreira Bastos, dirigiu-se até a subdelegacia de polícia do distrito para oferecer a denúncia de ferimentos e morte praticados por Dieter. Todos estavam "mansos e pacíficos", quando João Felipe Dieter e Carlos Sparrenberger começaram a trocar insultos e palavras ofensivas pelo fato de um animal (vaca) do segundo ter invadido e, provavelmente, destruído a plantação do primeiro. No interrogatório, Dieter afirmou que, por diversas vezes, solicitou ao vizinho Carlos que prendesse os seus animais ou então fizesse uma cerca para impedir que eles continuassem a destruir as suas plantações, o pedido, porém, não foi atendido. E afirmou ainda que, ao chegar à casa de negócio de Stumpf, por ocasião de um baile público, imediatamente, foi insultado e ofendido por Carlos, que "começou logo a enticar sobre esse pedido". ${ }^{16}$

Em 1846, dos trinta e três artigos que constituíam o Código de Posturas Municipais $(\mathrm{CPM})$, cinco tratavam, especificamente, sobre a obrigatoriedade de o lavrador/ agricultor construir cercas para proteger os seus animais em potreiros e evitar que eles invadissem e destruíssem as plantações dos vizinhos, motivo causador de diversos conflitos e desentendimentos entre os vizinhos. Apesar das penalidades previstas pelo CPM de 1846 e 1864, um abaixo-assinado, enviado no dia 8 de setembro de 1866, demonstra as dificuldades enfrentadas pelos lavradores e pelas autoridades locais em fiscalizar o cumprimento da lei e penalizar os infratores. Assim, dezesseis chefes de famílias, residentes em Dois Irmãos, reiteram que são "constantemente flagelados pelos seus vizinhos, que possuem seus gados soltos". Esses indivíduos, que vivem exclusivamente da agricultura, queixam-se da

[...] impropriedade da respectiva postura municipal, que, em vez de proteger a lavoura, protege os donos de animais que a estragam [...] obriga os lavradores a fazerem cercas quase impossíveis para terem direito a exigirem o pagamento dos danos causados pelos gados. ${ }^{17}$

Os artigos 29 e 30 do CPM de 1846 e o título $2^{\circ}$ do CPM de 1864, por exemplo, estabeleciam a obrigatoriedade de os lavradores e criadores de animais conservarem seus animais em potreiros cercados, porém, os lavradores do abaixo-assinado denunciam que a lei não era cumprida. Ao final do documento, os lavradores exigem que os possuidores e criadores de animais construam as cercas, a fim de proteger o potreiro e as lavouras dos vizinhos, pois tal medida contribuiria "efetivamente para a tranquilidade dos habitantes" da sede e dos distritos de São Leopoldo. ${ }^{18}$

Ainda sobre o caso envolvendo a família Sparrenberger e João Felipe Dieter, podemos visualizar que o indivíduo que teve sua lavoura destruída pelos animais do vizinho 
optou por não fazer uma queixa junto às autoridades locais sobre a questão, mas, sim, solicitar pessoalmente ao vizinho que providenciasse uma cerca para proteger seus animais e sua lavoura. Partimos do pressuposto de que tal situação ocorria com frequência, uma vez que Dieter confirmou que tinha inimizades com o vizinho há mais de três anos. Por fim, os jurados entenderam que o lavrador Dieter agiu em legítima defesa, sendo, por isso, absolvido da acusação em 1865. Insatisfeito com a sentença, o Juiz de Direito apelou para o Tribunal da Relação e solicitou novo julgamento, do qual o réu foi novamente absolvido, em 1866. ${ }^{19}$

Os conflitos e desentendimentos relacionados à abertura e ao fechamento de caminhos, associados à "demora e à irregularidade na medição e demarcação de terras" (TRAMONTINI; ENGSTER, 2004, p. 357-8) dos colonos, motivados pela invasão e destruição de propriedades por animais e pelo desaparecimento desses animais, permeavam as condições de sobrevivência dos indivíduos, geralmente vizinhos, e estavam interligados à conjuntura histórica, econômica e social de São Leopoldo. Infringir a lei e utilizar a violência como um mecanismo para resolução de questões cotidianas e, especialmente, para defender e garantir os direitos constituíram um habitus local dos indivíduos nas suas ações individuais e/ou na relação com sujeitos de outras origens étnicas. Todavia, é lícito destacar que tais situações não eram peculiares a São Leopoldo e suas gentes, pois foram identificadas por outros autores em outras regiões coloniais do Rio Grande do Sul (província) e do Brasil (império).

\section{Abstract}

This article analyzes some daily confrontations and conflicting episodes caused by economic issues involving Germans, their descendants and nationals in São Leopoldo between 1846 and 1871. In analyzing and quantifying the data of criminal cases it was verified that historical agents used violence in Situations of land disputes, problems arising from measurements and invasions of properties. Disagreements and conflicts occurred mainly among neighbors, friends and acquaintances. Thus, social relations could be permeated by networks of friendship, solidarity and reciprocity, but, on the other hand, these networks could be broken, generating enmities, strife and conflicts. We will look here, to look at the behaviors of the individuals involved in the quarrels, the motivations for the disputes and the context historical social actors.

Keywords: Criminality. Everyday life. Violence.

\section{Resumen}

Este artículo compara algunos confrontos cotidianos y episodios conflictivos ocasionados por las desviaciones envolventes, sus descendientes en São Leopoldo, entre 1846 y 1871. Para analizar y cuantificar los datos criminales, Situaciones de disputas de terras, problemas derivados de mediciones y invasiones de propiedades. Los desentendimientos y los conflictos se producen, sobre, entre vecinos, amigos y conocidos. Asi como, las relaciones sociales pueden, por un 
lado, ser permeadas por redes de amizade, solidaridad y reciprocidade, mas, por otro lado, las redes de podiam ser rompidas, gerando inimizades, rixas y conflitos. Buscaremos aquí, para los comportamientos de los sujetos involucrados en las querelas, como motivaciones para las disputas y el contexto histórico de los atores sociales.

Palabras clave: Cotidiano. Criminalidad. Violencia.

\section{Notas}

1 Não foi surpresa constatar que, dos 157 réus, 72 declararam estar ocupados em suas lavouras, visto se tratar de uma região voltada especialmente para a prática do mundo rural. Assim, as profissões ligadas à agricultura (lavrador/agricultor) aparecem em grande número, demonstrando que os réus ocupados em suas lavouras estavam mais propensos a envolver-se em conflitos e desentendimentos.

2 APERS, Processo crime, $1^{\text {a }}$ Vara Cível e Crime, número 3003, maço 59, estante 74, 1866.

3 APERS, Processo crime, $1^{\text {a }}$ Vara Cível e Crime, número 3003, maço 59, estante 74, 1866.

4 APERS, Processo crime, $1^{\text {a }}$ Vara Cível e Crime, número 3003, maço 59, estante 74, 1866.

5 APERS, Processo crime, $1^{\text {a }}$ Vara Cível e Crime, número 3003, maço 59, estante 74, 1866.

6 APERS, Processo crime, Tribunal do Júri, número 10, maço 1, estante 77, 1849.

7 APERS, Processo crime, Tribunal do Júri, número 10, maço 1, estante 77, 1849.

8 APERS, Processo crime, Tribunal do Júri, número 10, maço 1, estante 77, 1849.

9 APERS, Processo crime, Tribunal do Júri, número 99, maço 5, estante 77, 1869.

10 APERS, Processo crime, Tribunal do Júri, número 99, maço 5, estante 77, 1869.

11 APERS, Processo crime, Tribunal do Júri, número 99, maço 5, estante 77, 1869.

12 APERS, Processo crime, Tribunal do Júri, número 99, maço 5, estante 77, 1869.

13 APERS, Processo crime, Tribunal do Júri, número 66, maço 3, estante 77, 1865.

14 APERS, Processo crime, Tribunal do Júri, número 66, maço 3, estante 77, 1865.
15 APERS, Processo crime, Tribunal do Júri, número 66, maço 3, estante 77, 1865.

16 APERS, Processo crime, Tribunal do Júri, número 66, maço 3, estante 77, 1865.

17 AHRS, CMSL, Posturas políticas, caixa 3, Doc. 32B, 08/09/1866, fl. 1 e 2.

18 AHRS, CMSL, Posturas políticas, caixa 3, Doc. 32B, 08/09/1866, fl. 1 e 2.

19 APERS, Processo crime, Tribunal do Júri, número 67, maço 3, estante 77, 1865.

\section{Referências}

AMADO, Janaína. A revolta dos Mucker. 2. ed. São Leopoldo: Editora Unisinos, 2002.

AVÉ-LALLEMANT, Robert. Viagem pela Provincia do Rio Grande do Sul (1858). Belo Horizonte; São Paulo: Itatiaia; Editora USP, 1980.

BRASIL. Lei n. 601 de 18 de setembro de 1850. Disponível em: <http:/ /www.planalto.gov.br/ ccivil_03/Leis/L0601-1850.htm>. Acesso em: 13 jun. 2017.

CARNEIRO, Deivy Ferreira. Conflitos verbais em uma cidade em transformação: justiça, cotidiano e os usos sociais da linguagem em Juiz de Fora (1854-1941). 2008. Tese (Doutorado em História) - Instituto Federal de Ciências Sociais, Universidade Federal do Rio de Janeiro, Rio de Janeiro, 2008.

FREITAS, Felipe Berté. Cultura e práticas de violência na sociedade rural norte-rio-grandense. 2014. Dissertação (Mestrado em História) Programa de Pós-Graduação em História, Universidade de Passo Fundo, Passo Fundo, 2014.

MAGALHÃES, Dóris Rejane Fernandes. As questões de terra: comparando casos no Vale dos Sinos. In: DREHER, Martin N.; TRAMONTINI, Marcos Justo (Org.). Anais do XVI Simpósio de História da Imigração e Colonização: leituras e interpretações da imigração na América Latina. São Leopoldo: Oikos, 2007. 1 CD-ROM.

MOTTA, Márcia Maria Menendes. Fronteiras internas no Brasil do século XIX: um breve comentário. Vivências, Erechim, n. 33, p. 55- 
65, 2008. Disponível em: <http://www.cchla. ufrn.br/Vivencia/publicados_layout.html>. Acesso em: 8 nov. 2016.

OLIVEIRA, Leonardo Pianta de; TRAMONTINI, Marcos Justo. Os registros de título de propriedade de terras na zona colonial do Rio Grande do Sul, a partir da regulamentação da Lei de Terras. In: DREHER, Martin N. (Org.). Imigração \& imprensa. Porto Alegre: EST; São Leopoldo: IHSL, 2004. p. 362-365.

ROCHE, Jean. A colonização alemã e o Rio Grande do Sul. Vol. II. Porto Alegre: Globo, 1969.

TRAMONTINI, Marcos Justo. A organização social dos imigrantes: a colônia de São Leopoldo na fase pioneira (1824-1850). São Leopoldo: Editora UNISINOS, 2003.

TRAMONTINI, Marcos Justo; ENGSTER, Maria Isabel Cristina. A imigração alemã na historiografia rio-grandense: Pellanda, Porto e Truda. In: DREHER, Martin N. (Org.). Imigração $\mathcal{E}$ imprensa. Porto Alegre: EST; São Leopoldo: IHSL, 2004. p. 357-361.

ORTIZ, Helen Scorsatto. Costumes e conflitos: a luta pela terra no norte do Rio Grande do Sul (Soledade 1857-1927). 2014. Tese (Doutorado em História) - Programa de Pós-Graduação em História, Pontifícia Universidade Católica do Rio Grande do Sul, Porto Alegre, 2014.

VENDRAME, Maíra Inês. Ares de vingança: redes sociais, honra familiar e práticas de justiça entre os imigrantes italianos no sul do Brasil (1878-1910). 2013. Tese (Doutorado em História) - Programa de Pós-Graduação em História, Pontifícia Universidade Católica do Rio Grande do Sul, Porto Alegre, 2013. 